\title{
Velfærdsstatspolitik og velfærdsstatskritik
}

\section{Mogens Holm}

Velfærdsstatsforskningen har i de seneste år i hovedsagen handlet om selve statens indretning, om klassekampens indvirkning på udfyldning af politikkerne og om de økonomiske konsekvenser af velfærdspolitikkerne. Interventionernes indvirkning på arbejderklassens kulturelle, normative, sociale og politiske forhold har derimod i ringe udstrækning været genstand for analyse og diskussion.

I denne artikel vil jeg skitsere nogle problemfelter omkring arbejderklassens kampformer indenfor rammerne af det borgerlige demokrati, om den borgerlige offentligheds forudstrukturering af livsformer og om statspolitikken som trussel imod arbejderklassens privatsfære.

\section{Indledning}

Den danske velfærdsstats krampetrækninger har sat skub i den sociologiske og politologiske forskning på staten.

Velfærdsstatsforskningen ${ }^{1}$ har i de seneste år ekspanderet voldsomt. Efter den borgerlige Schlüter-regerings tiltrædelse er venstrefløjens interesse for velfærdsstatens funktionsmåde og politikgrundlag forøget. Der kan skimtes en vis nostalgi overfor den periode, hvor socialdemokratiet havde hegemoni over staten og udviklede velfærdsstaten. 80'ernes stats- og politikforskning har taget fat på kortlægning af velfærdsstatens udfyldning af statsapparatets funktionsmuligheder og funktionsgrænser.

Velfærdsstatens opkomst er foranlediget af socialdemokratiets fremgang i løbet af 60'erne, hvor lønarbejdets udvidelse forøgede partiets politiske grundlag og stemmetal ved folketingsvalgene. SD fik hegemoni over staten og havde i hovedsagen regeringsmagten - med korte afbrydelser - indtil 1982.

I denne periode udvikledes interventionsstatens foranstaltninger overfor arbejderklassens reproduktionsforhold.

1. Som udtryk for denne blomstring kan tages Center for Velfærdsstatsstudier som har organiseret forskere der arbejder med forskning af velfærdsstaten. De projekter, der bliver informeret om og som har været fremlagt på CVS'symposier i 1984 og 1985 er meget varierende og der kan ikke trækkes en rød tråd igennem deres hensigter og formål. Mine efterfølgende betragtninger om indholdet i forskningen bygger på fornemmelse, men kan afprøves ved at sammenholde min tese med indholdet i seminaret 1984, som er gengivet i et arbejdspapir »CVS-symposium«, Sociologisk institut 1984, og indholdet i plenumforelæsningerne i seminaret i 1985. 
I velfærdsstatsunders $\emptyset$ gelserne er det blevet bemærket, at arbejderklassen har bakket op bag SD og fagbevægelsen, og har givet styrke til realisering af velfærdspolitikkerne. Det er således arbejderklassen, der igennem politisk og faglig organisering har tilkæmpet sig de rettigheder og den sikkerhed, som velfærdsstaten indebærer.

SD og LO har kæmpet for deres interesser indenfor de rammer, som er sat af det borgerlige demokratis parlamentariske system. Interesseartikulationen er omgrænset af de borgerlige spilleregler, formidlet igennem et demokratisk centralistisk repræsentationssystem, sorteret af det offentlige bureaukrati og fjernet fra den basis hvorfra interesserne stammer.

Klassekampens aktioner filtreres ind i en borgerlig offentlighed, som medfører en institutionalisering af kampen. Kampperspektivet på »gulvet« bliver til interesseformidling igennem det politiske bureaukrati, og netværket imellem arbejderne bliver til et repræsentationssystem i den borgerlige offentligheds institutioner.

Den demokratiske parlamentarisme er offentlighedsrammen bag velfærdspolitikken. Det er herigennem de private reproduktionsinteresser bliver til offentlige interventioner.

De velfærdsstatslige interventioner har altså flere aspekter og konsekvenser end den indkomstoverførsel og den sociale sikkerhed, som velfærdsstatsforskningen beskæftiger sig med igennem en fokusering på statsfunktioner og statsmagt. Politikken virker også ind på arbejderklassens privatssfære, privatlivet, på sociale-, kulturelle og politiske forhold, på bevidstheden og kollektiviteten.

Velfærdsstatsforskningen overser interventionernes indflydelse på arbejderklassens befrielseskamp. Kampen for befrielse starter i klassens selvorganisering, bearbejdelse af erfaringer med undertrykkelsen og udvikling af et »selvrådigt « demokrati. Den borgerlige offentlighed hæmmer disse elementer i befrielseskampen, og har således indflydelse på friheden og tvangen i arbejderklassen.

Denne artikel er først og fremmest en tematisering af aspekter af velfærdsstatens funktioner, som den traditionelle forskning ser bort fra. Men der lægges også op til et andet forskningsprogram om reformismens understrømme, der skylder ind under arbejderklassens grund i privatssfære, kultur og normer, som bliver truet og måske ødelagt.

\section{De politiske perspektiver $i$ statskritikken}

Den danske venstrefløj er på flere måder blevet taget på sengen i statskritikken. I første omgang har det været centralt for den socialistiske politikforskning at kritisere den statslige udvikling, men samtidig måtte den tage til efterretning, at staten også var en nødvendighed for arbejderklassen. Dernæst har venstrefløjen indgået i strategiovervejelser angående statens fortsatte udvikling og på dette grundlag udarbejdet krav til dens ekspansion. I dette 
temafelt er venstrefløjen - stort set omfattende alle grupper på fløjen - endt i en modsigelse mellem på den ene side at kritisere statens funktioner og på den anden side kritisere, at staten ikke udvider disse funktioner.

Michael Kråtke mener, at venstrefløjen er løbet ind i en modsætning ved

»... på den ene side (at have) indvendt imod velfærdsstaten, at den officielle målsætning - i retning af at overvinde nød og social usikkerhed - principielt ikke kunne realiseres under kapitalisme. På den anden side har venstrefløjen altid målt dens præstationer i forhold til disse målsætninger og bebrejdet den, at den kun realiserer dem utilstrækkeligt... $\ll^{2}$

Konsekvenserne af statskritikken peger ikke i retning af fjernelse af den borgerlige stat, ihverttilfælde ikke før kommunismen er gennemført. Og indtil da har venstregrupperingerne ikke noget svar på antagonismen i velfærdsstaten, men peger på ineffektiviteten og den udeblivende sociale lighed. Samtidig forekommer der ikke noget alternativ indenfor det borgerlige demokratis og parlamentarismen rammer, og derfor er spørgsmålet om realisme i hovedsagen et pragmatisk forhold.

Konsekvensen er en akcept af velfærdsstatens funktioner og på dette punkt er der betragtelige ligheder imellem de borgerlige og de socialistiske partiers indstilling til velfærdsstaten. De borgerlige partier splittes ligeledes imellem afsky overfor og akcept af velfærdsstaten. Den borgerlige politik har tilbagevenden til neo-liberalisme på dagsordenen, og ser på den måde velfærdsstaten som en institution der forsøger at helbrede en sygdom, som den selv er anledning til. På den anden side er det ikke den værste måde at organisere det borgerlige samfund på og forsåvidt forekommer, der ikke noget alternativ.

Den borgerlige politik har også et antagonistisk forhold til velfærdsstaten ved på den ene side at være kritisk overfor velfærdspolitikkens skadelige indvirkning på markedsøkonomien, men på den anden side at se dens nødvendighed i øjnene.

»Den pinlige hemmelighed ved velfærdsstaten er, at mens dens indflydelse på den kapitalistiske akkumulation nok kan være destruktiv (som den konservative analyse så udtrykkeligt påviser), ville dens afskaffelse være direkte nedbrydende, (en kendsgerning som de konservative kritikere systematisk ignorerer) ${ }^{3}$.

Den væsentligste forskel på venstre og højre politik handler ikke så meget om forholdet til velfærdsstaten, men langt mere om holdning til alternative

2. Michael Krätke. Om velfærdsstatens politiske $\emptyset$ konomi - og den ufuldkomne kritik deraf, $i$ Kurasje nr. 34, 1984.

3. Claus Offe. Nogle modsætninger i den moderne velfærdsstat, $i$ CVS-symposium, Sociologisk institut 1984. 
muligheder for organisering af det sociale sikkerhedsnet. Herom har venstrefløjen - principielt - et andet samfundsbillede som grundlag for forestillingen. Den bevidste arbejderklasse og det levende proletariat har en plads i venstrefløjens samfundsbillede, men er helt udenfor den borgerliges. På dette punkt er der væsentlig forskel på den socialistiske og den borgerlige politik, men problemet er at venstrefløjen ikke har gjort anvendelse af de dele af samfundsbilledet, som bygger på socialistisk demokrati og selvorganisering.

Venstrefløjen har simpelthen glemt tilstedeværelsen af proletariatets erfaringer og evne til selvorganisering, og en vigtig grund hertil er, at arbejderklassen også selv har glemt evnen til erfaringsindsamling i kollektive sammenhænge, i takt med at disse elementer er blevet hæmmet af den velfærdspolitik, som har gjort selvorganiseringen overflødig og selvrådigheden til en møllesten om halsen på det borgerlige demokrati.

Venstrefløjens kritik af staten har ikke medført udvikling af alternative løsninger til de offentlige socialpolitiske interventioner. Udvikling af alternativer har været hæmmet af en skræk for, at alternativer til det offentlige tages som bidrag til den privatiseringsform, som den borgerlige regering pt. lancerer. Dette dilemma har ført til den holdning, at statsfunktionerne er kritisable, og desuden er der al for lidt af dem.

\section{Nogle historiske trak af fagbevagelsens og socialdemo- kratiets indflydelse på velfardsstatens udvikling}

Den danske fagbevægelse og SD har i fællesskab haft omfattende indflydelse på den socialpolitiske og arbejdsmarkedspolitiske udvikling, især i perioden efter 1960. Denne indsats har givet den danske arbejderklasse forskellige former for sikkerhed i reproduktionen.

Det vigtigste mål for velfærdspolitikken har været at sikre grundlaget for reproduktionen i situationer med indkomstbortfald - pga. sygdom, arbejdsløshed - at udligne forskelligheder i reproduktionsomkostningerne - børnepenge, boligsikring - og at statsliggørelse visse dele af husarbejdet igennem institutioner til pasning af børn, unge og ældre -vuggestuer, børnehaver, fritidshjem og alderdomshjem.

Velfærdspolitikken har således både tjent det formål at gøre arbejderklassens reproduktionssituation tryg - ved tab af løndindkomst bryder familielivet og boligsituationen ikke sammen - og at sikre arbejdsevnens opretholdelse, at klassen genskabes og, at der er kontinuerlig leverance af arbejdskraft til markedet som søges reguleret i forhold til efterspørgslen.

I velfærdspolitikken er der både sociale og arbejdsmarkedsmæssige aspekter. Velfærdsstatens interventioner har medført vigtige forbedringer i arbejderklassens livs betingelser og resultatet har i høj grad været en succes for det socialdemokrati der har kæmpet for det sociale sikkerhedssystem. 


\section{Men den danske socialpolitik har også varet forbundet med omkostninger for arbejderklassen:}

Arbejderbevægelsens historie i begyndelsen af dette århundrede, indeholder eksempler på, hvordan arbejderklassen selv har udviklet løsninger på de problemer, der er opstået når kapitalismen har været i krise, når arbejdsløsheden har grebet om sig og lønindkomsten er forsvundet.

Der er eksempler på, at arbejderne selv har igangsat produktion, organiseret hjælpekasse til de fattigste og lavet forsikringer i forbindelse med sygdom. ${ }^{4}$ Løsningen af de sociale problemer har i visse perioder været funderet $\mathrm{i}$ arbejderklassens egne beslutninger og normer for solidaritet. Der er eksempler på, hvordan grupper af arbejdere omkring arbejdspladser eller boligområder har måttet tage stilling til i hvilket omfang økonomiske og sociale problemer skal kollektiviseres og løses i fællesskab. Denne form for selvorganisering har forudsat tilstedeværelse af et socialt netværk og har givet muligheder for udvikling af kollektive erfaringer. ${ }^{5}$

Nødvendigheden af arbejderklassens selvorganiserede løsninger på livets problemer er en følge af klassens frihed fra produktionsmidler og frihed for tvang; en frihed der har været en hindring for kapitalismens frie udfoldelse og som har nødvendiggjort en mere institutionaliseret organisering igennem fagforeningerne og igennem socialdemokratiet.

Det selvorganiserede sikkerhedsnet er der ikke nogen anledning til at romantisere. Det har været skrøbeligt, kun omfattet visse lokale arbejderforeninger og meget afhængig af det materielle grundlag som den pågældende gruppe af arbejdere har været $\mathrm{i}$ besiddelse af.

Kapitalismens udvikling har stadig ikke givet mere omfattende muligheder for udvikling af selvorganisering, men har i den hidtidige periode forøget behovet for ensartede forhold $\mathrm{i}$ hele nationen funderet i et lovkompleks, der gælder for alle og son sikrer genskabelse af arbejdsevnen.

For arbejderklassen har den lokale selvorganisering været utilstrækkelig i forhold til udviklingen på arbejdsmarkedet og der har udviklet sig et krav om ensartede reproduktionsbetingelser, som forudsætningen for lige betingelser for konkurrencen på arbejdsmarkedet.

Arbejderklassen har altså, igennem arbejderbevægelsen og arbejderpartiet, kæmpet for indførelse af det lovkompleks som er grundlaget for udviklingen i interventionsstaten og for den offentlige indblanding i klassens reproduktions-

4. Se Michael Vester. Proletariatets opståen som læreproces. Historievidenskabens skriftserie no. 7. Forlaget GMT 1978. Der bygges her på erfaringerne i England i perioden 1832-1834, hvor der oprettes syndikalistiske industrifagforeninger og udvikledes kooperative institutioner. Som svar på den teknologiske arbejdsløshed satte arbejderne selv produktionen igang.

5. I bogen »Family and Kinship in East London«, Pelican Book, A595, skriver Michael Young og Peter Wilmout om forholdene i Londons arbejderkvarterer i omkring 1950. 
forhold. Dette er et element i reformismen: På den ene side stiller arbejderklassen krav om sikkerhed i reproduktionen, og på den anden side bliver dette krav tilfredsstillet på betingelse af den borgerlige stats herredømmeforhold.

\section{Velfardspolitikkens grundlag og konsekvenser under højkonjunkturen}

\section{Statens planøkonomi og privatsfæren}

Forsøget på at introducere en planøkonomi blev startpunktet for udvikling af den politik, som skulle involvere staten i markedsmekanismerne, et fors $\varnothing \mathrm{g}$ på at dæmpe og styre markedssvingningerne og på at regulere produktionen af arbejdskraft. »Planøkonomien« vandt aldrig indpas i Danmark, men der indførtes i stor udstrækning reguleringer inspireret af keynes økonomiske teori, hvor offentlig kontrol med relationen imellem konsum og produktion igennem forøgede offentlige udgifter, betragtedes som værende ønskeligt og nødvendigt.

Det danske socialdemokrati har forsøgt - og i nogen udstrækning er det lykkedes - at anvende økonomisk planlægning i noget man kunne kalde en socialiseret form, for at afhjælpe kapitalismens krisetendens, fordele indkomsten blandt lønarbejderne, sikre den fulde beskæftigelse, og for at mobilisere og frigøre arbejdskræfter. Den $\emptyset$ konomiske planlægningspolitik blev realiseret i sociale reformer som opprioriterede offentlige udgifter.

Ideologien bag den socialdemokratiske velfærdspolitik har på længere sigt været demokratisk vej til socialisme, og på kortere sigt har det været vejen til fjernelse af social ulighed og til ligestilling imellem kønnene.

De offentlige tilskud til arbejderfamilier med høje reproduktionsomkostninger, f.eks. pga. mange børn, dyr bolig m.v., har haft en kompenserende effekt på variationerne mellem leveomkostninger og lønindkomst. Men stadig er der kun tale om omfordeling indenfor klassen af lønmodtagere, og den danske skattelovgivning har siden 1950'erne, været sådan indrettet at det er mellemindkomsterne, der betaler til de lavestlønnede, eller til de der overhovedet ikke har lønindkomst. De højestlønnede arbejdere rammes i ringe udstrækning, fordi de har muligheder for at anvende de forskellige skattefordele.

Velfærdspolitikkens indflydelse på de sociale uligheder har således nogle begrænsninger. For det første fordi udjævningen ikke har indflydelsen på forskellen imellem klasserne, og for det andet fordi udjævningen indenfor selve arbejderklassen kun omfatter en mindre del.

Den fundamentale forudsætning for understøttelse og omsorg har været behovet for frigørelse af arbejdskræfter til arbejdsmarkedet. Dette har medført at en større andel af den totale »arbejdskapacitet« er blevet placeret i produktionen og en faldende andel som arbejde i forbindelse med reproduktionen og regenerationen per familie i arbejderklassen. I perioden fra 
1930'erne til i dag har den fulde arbejdstid pr. familie indeholdende to voksne af modsat køn og evt. et antal børn, er steget.

Selv om teknologiudviklingen nødvendigg ør mindre arbejdstid pr. fremstillet produktenhed giver ægtefæller i 60'erne mere arbejde til udbytning og undertrykkelse i den kapitalistiske produktion end de gjorde i 1930.

Den offentlige sektor er blevet udvidet på reproduktions- og regenerationsområdet til forøgelse af arbejderklassens sociale sikkerhed, men samtidig har det bureaukratiske system ekspanderet til registrering og kontrol af ydelsesmodtagerne. Modtagelse af forskellige former for sociale hjælpeforanstaltninger forudsætter ikke alene, at modtagerne skal dokumentere et behov for ydelsen, men yderligere også har en adfærd, der er »klientværdig«. Ved modtagelse af socialhjælp - f.eks. i forbindelse med bortfald af løn ved arbejdsløshed, sygdom eller ulykke - forudsætter bistandskontoret indblik i modtagerens private $\varnothing$ konomi, og i nogle tilfælde, f.eks. i forbindelse med kontanthjælp, fremlæggelse af budget og regnskab for det private forbrug. Bistandskontoret har kun mulighed for at dække dele af udgifterne, hhv. tvinge modtageren til at ændre sine $\varnothing$ konomiske forhold, f.eks. ved at underkaste sig af-alkoholisering, som forudsætning for ydelsens modtagelse.

En anden og måske vigtigere pointe er det offentliges overtagelse af en del af den børneopdragelse og omsorg som tidligere foregik i familien. Disse opdragelses- og omsorgsinstitutioner drives af offentligt ansatte professionelle socialarbejdere og pædagoger, der er uddannet på de statsligt drevne uddannelsesinstitutioner. Dette er ikke en kritik af forskellige typer af professionelle socialarbejdere i de offentlige sociale institutioner, men er en måde at gøre opmærksom på den betydning, som staten har på opdragelse og socialisering, udvikling af sociale normer og borgerlige sædvaner. Og dette er også en måde at motivere til utopisk tænkning om socialt arbejde organiseret udenfor det offentlige regi, med professionelle socialarbejdere organiserede f.eks. af fagforeningerne, af sociale bevægelser eller i boligområderne.

I Danmark kan man tale om statslig socialisering af befolkning fra vugge til grav og som konsekvens heraf, offentlig kontrol med kulturel udvikling og sociale normer. Denne udvikling af den borgerlige stats kontrol gør det meningsfuldt at diskutere indholdet i de offentlige interventioner. Hensigten her er en vis ensretning - homogenisering - via en regulering fra den statslige administration. Vi står her overfor en vis ensretning af uddannelsens og opdragelsens indhold, der ser bort fra individuelle kvalifikationer og fra børn og unges klasse-specifikke erfaringer.

I denne diskussion er der fra min side ikke taget stilling til om opdragelse i kernefamilien er at foretrække frem for opdragelse i offentlige børnehaver og fritidshjem. Det er min hensigt, at understrege at den forøgede offentlige intervention i børneopdragelsen indebærer muligheden for forøget offentlig kontrol, og indebærer risikoen for at klasseerfaringerne udskiftes med borgerlige normer og holdninger. 


\section{Familiepolitik og familien}

»Par princip« er familien et fristed for arbejderklassen, fordi hverken stat eller kapital har muligheder for direkte tvangsforanstaltninger overfor familien. Der er ikke nogen instans der kan tvinge arbejderne til at leve i kernefamilie. Ikke desto mindre lever $70 \%$ af den voksne befolkning i kernefamilie i dag (1985), i familier bestående af to modsatkønnede voksne evt. med et antal børn ${ }^{6}$.

Staten har meget ringe muligheder for tvangsmæssige foranstaltninger overfor familien og overfor familiens medlemmer. Det gælder både i forbindelse med at tvinge familien til en bestemt boligform, til anvendelse af børnehaver og fritidshjem, og det gælder også mht. at beskytte familiens medlemmer overfor vold og mishandling i familien. Imellem familiens medlemmer gælder der helt andre regler og praksis, end når det drejer sig om vold og voldtægt på offentlige steder eller i forhold til personer udenfor familien.

Men statens interesse i interventioner overfor familien er stor og disse kontrol- og reguleringshensigter har måttet gennemføres på andre måder end igennem direkte tvang.

Hele det familiepolitiske område indeholder tilskyndelser og tilbud, som omgiver arbejderfamilierne som adfardsrammer. I valget af bolig, børneproduktion og konsumvaner indarbejdes denne adfærdsramme, som en forudsætning for etablering af en livsform på et gennemsnitligt niveau.

Uden anvendelse af tvang er familien blevet et formidlingscentrum for mange statslige interventioner, hvor hensigten såvel kan være resultater indenfor familien som udenfor familien ${ }^{7}$. Disse hensigter kan deles op i 3:

1. Interessen for regulering af børneproduktionen har en lang historie bag sig. Indenfor disse rammer kan jeg ikke bidrage til afklaring af sammenhængen, men befolkningens regeneration ved egen drift har i flere århundreder ikke været i balance, efter statens opfattelse ${ }^{8}$.

I visse perioder har der været tilskyndelser til øgning af børneproduktionen og i andre perioder til formindskelse af børneproduktionen. Dette er også gældende for den danske velfærdsstat der på forskellige måder har søgt at påvirke fødselstallet, bl.a. igennem børnetilskud, hjælp ved fødslen, tilskud til svangerskabsforebyggende foranstaltninger, tilbud om skattelettelser ud fra børneantal, fri abort - godt nok med ringe resultat.

6. Til uddybningen af det statistiske materiale om udviklingen i familiestrukturen kan henvises til mit paper »Changes in the Danish Family Life since Second World War «, Arizona State university 1984. Kan fås på Sociologisk institut, Linnésgade 22, 1361 København K.

7. Bygger på J. Donzelot, Policing in the Families, London 1979. Især afsnit 3, Government through the family, s. $48 \mathrm{ff}$.

8. Se yderligere Heinsohn, Knieper, Steiger, Menneskeproduktion, Forlaget Kurasje/Sociologi 1981. 
2. Regulering af arbejdskraft til rådighed på arbejdsmarkedet. Igennem offentlig institutionalisering af omsorg for børn, unge og gamle har staten bidraget til frigørelse af arbejdskraft til kapitalens udbytning og undertrykkelse.

3. Endelig har interessen for familiepolitik haft hensigter, der i og for sig ikke har noget med selve familieforholdet at gøre. Det drejer sig om den offentlige kontrol med hygiejne, det drejer sig om sikring af undervisningsniveauet og om indarbejdelse af borgerlige normer og holdninger. Disse hensigter forfølges f.eks. igennem de offentlige børnehaver og det offentlige skolesystem ${ }^{9}$.

Forøgelsen af den mængde arbejde som skal leveres til produktionen pr. familie (nu arbejder to voksne, mod tidligere 1 voksen pr. familie) - har ikke medført et tilsvarende fald i husarbejdet. Selv om husarbejdet industrialiseres - vaskemaskiner, prefabrikeret madvarer, anvendelse af syntetiske byggematerialer m.v. - er husarbejdet ikke afskaffet og kan antagelig aldrig helt forsvinde. Selv med den enorme teknologiske udvikling på dette område kan husarbejdet ikke helt fjernes. Den kvindelige arbejdskrafts forøgede anvendelse i produktionen har ikke medført en tilsvarende aflastning i husarbejdet, som traditionen tro i ægteskaber og ægteskabslignende familier, i hovedsagen udføres af kvinden. Dette viser bl.a. en tidsforbrugsunders $\varnothing$ gelse udført af Socialforskningsinstituttet. Man kan derfor regne med at velfærdsstatsudviklingen har medført forøget belastning af kvinderne igennem denne form for dobbeltarbejde.

Selvom der har været en forbedring af arbejderklassens materielle levevilkår, er det et spørgsmål, om der i dag er større lighed imellem kønnene end for 30 år siden. Men det er klart at en del af uligheden imellem kønnene direkte er et resultat af velfærdspolitikken.

Tidligere i arbejderklassens historie har familien været en central social enhed, hvorigennem problemerne blev løst på tværs af kernefamilien, igennem større familiesammenkædninger og på tværs af kernefamilierne i boligområderne ${ }^{10}$. Disse sammenkædninger gav muligheder for erfarings-udveksling og bearbejdning og en social kontrol fra bunden. Der eksisterede proletarisk offentlighed, som indeholdt arbejderklassens eget sprog, normer og kultur, som var funderet i arbejderfamilierne selv.

\section{Den proletariske offentlighed og social kontrol}

Jeg har tidligere nævnt, at arbejderbevægelsen og arbejderpartiet har formidlet arbejderklassens interesser indenfor rammerne af det borgerlige demokratis parlamentariske rammer. I denne proces omringes klassekampen af de

9. Birthe Siim. Velfærdsstat og patriarkat, $i$ Grus nr. 6, 1982. Elizabeth Wilson, Women and the Welfare State, Tavistock. London 1980.

10. Young og Willmout, op.cit. 
borgerlige institutioner og organisationsformer, med repræsentationssystemer, valgordninger osv. der medfører, at arbejderklassens aktioner i reproduktionskampen bliver indsyltet i borgerlig offentlighedsformer. Denne adskillelse imellem de fundamentale kampperspektiver og reproduktionsbehov og så de politiske løsninger hæmmer udviklingen af arbejderklassens egne offentlighedsformer, der sætter af fra kollektiv bearbejdning af erfaringer, deltagelse i løsning af sociale problemer, livssammenhænge og samtidighed ${ }^{11}$.

I selve arbejderklassens konstitution ligger friheden til at organisere livet udenfor produktionen på egne præmisser. Friheden fra produktionsmidler og fra tvang indebærer som udgangspunkt, at klassen har frihed til at organisere privatssfæren, som et frit valg. Kapitalismens udvikling har medført omfattende begrænsninger i frihedens realitet og de seneste årtiers politikudvikling har forøget kontrollen og yderligere hæmmet den proletariske offentlighed. Den proletariske offentlighed er et alternativ til den borgerlige offentlighed som bygger på arbejderklassens kollektive erfaringsbearbejdelse, selvorganisering og samtidighed. Udvikling af proletarisk offentlighed er en modaktion overfor den ødelæggelse af livssammenhængene som kapitalismens adskilthed, usamtidighed og herredømme medfører.

Når velfærdsstatsforskningen diskuterer interventionernes funktion i arbejderklassens sociale sikkerhed er det vigtigt at betragte de konsekvenser velfærdsstaten har for arbejderklassens reproduktionskamp.

Min tese er, at udviklingen af velfærdsstaten bremser arbejderklassens muligheder for at indsamle og kollektivisere sociale erfaringer fra en generation til den næste, og dermed også begrænset muligheden for udvikling af den proletariske offentlighed, som ifølge Negt og Kluge ${ }^{12}$ er resultat af kollektiv bearbejdning af erfaringer med emancipatorisk perspektiv. Denne proletariske offentlighed står i modsætning til den borgerlige offentlighed, hvor erfaringsbearbejdningen erstattes af repræsentativ parlamentarisme. Den borgerlige offentlighed er således begrænsende for arbejderklassens erfaringsbearbejdning og står i vejen for den proletariske offentlighed. Således må velfærdsstaten opfattes som hindring for arbejderklassens emancipation og selvrådighed.

\section{Velfardspolitik i den aktuelle krise: Udviklingen fra sikring af levevilkår til socialhjaelp}

Velfærdspolitikkens udvikling i perioden med fuld beskæftigelse har ikke kun været en dans på roser for arbejderklassen. Den samfundsmæssige udvikling har budt på forbedrede materielle betingelser og forøget sociale sikkerhed,

11. Oskar Negt og Alexander Kluge har skrevet om dette i bogen Geschichte und Eigensinn, 2001, Frankfurt A/M 1981. Jørgen Falk har i artiklen Historien og utidigheden, Kontekst nr. 46/1984 fremhævet og fortolket bogens hovedpointer.

12. Ibid. 
men udviklingen har også medført omfattende sociale forandringer, intensivering af arbejdet og indførelse af dobbeltarbejde for kvinder. Det må ikke gå i glemmebogen, at forbedringen af levestandarden, flere materielle forbrugsgoder til rådighed, er baseret på at arbejderfamilien i dag i gennemsnit stiller flere arbejdstimer til rådighed for arbejdsmarkedet og for udbytningen - pga. kvindernes forøgede erhvervsfrekvens siden 2. verdenskrig.

Krisesituationen har gjort det umuligt for SD at opretholde kontrollen med statsapparatet. SD er blevet nødt til at tage afsked med denne form for velfærdspolitik, som i lang tid har været en succesfuld måde at organisere det borgerlige samfund på. Mulighederne for at opretholde det sociale velfærdssystem er indskrumpet, og med det aktuelle niveau af arbejdsløshed (forår 1985) er behovet for sociale ydelser steget, samtidig med at ydelsernes finansieringsgrundlag er indsnævret. SD har ikke været i stand til at opretholde det sociale sikkerhedsnet som blev introduceret i 1960'erne.

Det politiske og økonomiske grundlag er forsvundet for fortsættelse af velfærdsstaten. Men samtidig er det heller ikke muligt at fjerne hele velfærdsstatskomplekset fra den ene dag til den anden, med et slag. Medens der på regeringsplan, igennem mange år har været taget beslutning om, at væksten i de offentlige udgifter skal stoppes, er resultatet udeblevet, og det har vist sig nødvendig at gennemføre en radikal rationaliseringspolitik, hvilket har været muligt for den borgerlige regering uden relation til fagbevægelsen.

Regeringen har søgt at løse problemet ved at nedskære de sociale ydelser (arbejdsløshedsunderst $\varnothing t t e l s e$, bistandshjælp) og ved at privatisere dele af den offentlige service, bl.a. indenfor det sociale område. Dette reorganiseringsprogram satser også på en nedskæring af forskellige offentlige institutioner, hhv. forøge brugernes egen-betaling heraf, således at en del af pasning og forsorg overfor børn, unge og ældre overlades til familierne.

Som tidligere nævnt har de offentlige interventioner overfor arbejderklassens reproduktionsforhold også haft en bagside ved at indvirke på deres privatliv og reproduktionsform. Tendens til offentlig institutionalisering siden 2 . verdenskrig har ændret den sociale struktur i arbejdernes liv. Denne struktur, og det urbane miljø, boligområderne, er ændret på en sådan måde at det nu, hverken erønskeligt eller muligt at gen-etablere familien, som den primære sociale enhed for forældre, socialiseringsenhed for den opvoksende generation og omsorg for de gamle. Befrielse fra de offentlige institutioner kan ikke foregå igennem reprivatisering af disse funktioner tilbage til familien.

Den borgerlige regerings reorganiseringsprogram vil medføre en tilbageføring af sociale funktioner til familien som der ikke længere er noget grundlag for. Reorganiseringsprogrammet er reaktionært, fordi der ikke længere er basis for disse omsorgsfunktioner i familiestrukturen. Det er også reaktionært, fordi nedskæringerne i finansieringen af de offentlige institutioner, og stigningen i arbejdsløsheden, først og fremmest rammer kvinderne. Derfor 
får privatiseringsprogrammet stor betydning for ligheden/uligheden imellem kønnene på arbejdsmarkedet og $\mathrm{i}$ familien.

Venstrefløjens dilemma imellem statskritik og krav om øget socialpolitiske foranstaltninger hænger antagelig sammen med, at råbet om nedlæggelse af offentlige institutioner, lukning af bistandskontorerne fører lige i armene på Kristeligt Folkeparti og Det Konservative Folkeparti.

Men kritikken af arbejderklassens afhængighed af velfærdsstaten medfører ikke at funktionerne og reproduktionsansvaret tilbageføres til familien. Kritikken bør medføre demokratisering af institutionerne, fjernelse af den sociale kontrol og overførsel af midler for det sociale område, til arbejderklassens selvforvaltning. Som sagt har familiestrukturen forandret sig de sidste 30 år og den gode gamle far-mor-barn leg vender aldrig tilbage. Hvis reprivatiseringsprogrammet realiseres - kvinderne bortføres fra arbejdsmarkedet og tilbagevises til husarbejde, med ansvar for forsorg med de opvoksende og bortdøende generationer - vil familien udvikle sig til et konfliktcentrum.

Nedskæringerne i de sociale ydelser er et hårdt slag for arbejderklassen. Velfærdsstaten har i en lang periode overtaget ansvaret for reproduktionen og for den sociale sikkerhed, og i takt dermed er grundlaget for selvorganisering og erfaringen med selvorganisering forsvundet. Arbejderklassen befinder sig i dag i en blindgyde på den måde, at selvorganiseringen er forsvundet, velfærdsstaten er på vej væk og der er ikke længere kollektive løsninger på krisens fattigdom og elendighed.

\section{Definition af sociale bevagelser}

Den opblomstrende interesse for de sociale bevægelser hænger sammen med deres position som et alternativ til partier og fagforeninger. Det påfaldende er formulering af behov og krav udenfor det borgerlige samfunds politiske institutioner. Begrebet sociale bevægelser står som en samlebetegnelse for sammenslutninger af et vist politisk socialt indhold, der er placeret udenfor parti og fagforeninger.

Bevægelsernes politiske betydning har været diskuteret, især ud fra spørgsmålet om hvorvidt de står i et modsætningsforhold til parti og fagbevægelse, eller i et symbiotisk forhold.

For at føre denne diskussion må det præciseres, hvad der skal forstås ved sociale bevægelser, og hvilke bevægelser der overhovedet kan påberåbe sig interesse fra et kritisk forskningsperspektiv. Spejderbevægelsen og Jehovas vidner er også bevægelser, men det er antagelig ikke tilstrækkelig grund til at beskæftige sig med dem.

De sociale bevægelser der er relevante set ud fra et kritisk perspektiv må have et politisk perspektiv, der er markant i forhold til den samfundsmæssige udvikling. Grundlaget for at skelne imellem sociale bevægelser og politikkens $\emptyset$ vrige samfundsinstitutioner er at bevægelserne må have taget politisk 
afsæt fra partier og organisationer; et politisk afsæt som er konstitutionsgrundlaget for bevægelsens udvikling.

Her foretages en afgrænsning af de bevægelser, der politisk er funderet som alternativ til partier og fagforeninger, og som er opstået som en modaktion overfor klassekampens institutionalisering.

Denne afgrænsning er nødvendig for at få et begreb om grunden til, at aktiviteterne ikke er kanaliseret ind i allerede eksisterende partier og faglige organisationer. Men afgrænsningen er også nødvendig for at udskille alle de klubber og foreninger, som der muligvis er »bevægelse« $\mathrm{i}$-men som ud fra et politisk synspunkt er uinteressant, og som i samfundsmæssig forstand ikke kan betragtes, som en politisk faktor.

De organisatoriske former i de sociale bevægelser er der en hel del usikkerhed omkring.

I litteraturen om sociale bevægelser er der flere bud på det organisatoriske indhold i de sociale bevægelser og om de forskellige måder, som de sociale bevægelser organiserer sig på. Men der synes at være en enighed om at de sociale bevægelser i det store hele er mere basisorganiseret end de traditionelle partier og faglige organisationer.

I stedet for kun at diskutere de organisatoriske forhold, er det nødvendigt at sammenkæde dette med grundlaget for at erfaringsdannelse og kollektiv bearbejdelse af erfaringerne, som ikke kun er bestemt af organisationens hierarkiseringsgrad. Grundlaget for individuel erfaringsindsamling er deltagelse i beslutningsprocesser og i problemløsninger, og den kontinuere anvendelse af samlede erfaringer forudsætter fortsat medvirken til problemløsninger og deltagelse i beslutningsprocesser. Erfaringsindsamlingens betydning for udvikling af kultur og normer er afhængig af disse erfaringers genanvendelse og indhøstning af nye erfaringer på dette grundlag. Det drejer sig altså om at gфre erfaringer, og gфre erfaring med erfaringerne.

På dette grundlag kan forskningsfeltet for kritisk social-bevægelsesforskning skitseres som værende de sociale grupperinger, hvor erfaringsdannelse og kollektiv erfaringsbearbejdelse ikke blokkeres, hvor den proletariske offentlighed har muligheder og hvor aktivitetsmålet tager afsæt fra de etablerede partier og organisationers politiske indhold.

\section{Utopi og alternativer}

Det er ikke meningen med denne artikel at udarbejde handlingsvejledning for arbejderklassen. Afslutningsvis vil jeg imidlertid nævne nogle alternativer og utopier - de er ikke realiserbare, men det er jo netop karakteristisk for utopier men kan give anledning til at tænke kritik af staten og de politiske praksis på.

Venstrefløjens kritik af staten som kapitalens »forlængede arm « har været en kritik af statens måde at organisere arbejderklassens udbytning og undertrykkelse på. 
Men denne indsigt har ikke haft nogen effekt på de radikale politiske programmer, der stiller krav til statens sikring af opdragelse og omsorg. I venstrefløjen har socialistisk kollektivisering af det borgerlige samfund, opsigtsvækkende nok, altid gået igennem statsliggørelse.

Dette hænger muligvis sammen med adskillelse imellem de personer, der udfører statskritik - oftest statstjenere på de højere uddannelsesinstitutioner, hvor arbejdet er forbundet med en vis autonomi - og så de grupper som staten kommer under behandling: langtidsledige, invalider, plejehjemspatienter osv. Problemet kan udtrykkes med Peter Brüchners ord: Staten kritiseres mest af dem, den endnu ikke har haft under behandling.

Statskritikkens resultater vedrører hele den gruppe af befolkningen, der er afhængig af staten, spændende fra statstjenere til de klienter der er under statens behandling. Kritikken af staten må derfor pege imod alternativ tænkning i relation til bistandskontorer og offentlige omsorgsinstitutioner.

Velfærdspolitikken har også haft indflydelse på venstrefløjens kampformer, som i omfattende grad er blevet institutionaliseret. Parolen for afinstitutionalisering af interessekampen er ikke kun relevant for arbejderklassens politiske bevægelse, men for venstrefløjen i det hele taget.

I socialistisk perspektiv er parolen om afinstitutionalisering af interessekampen central for den danske venstrefløj og skal anvendes i udvikling af selvorganisering, autonomi og selvrådighed.

Forandringerne i livsbetingelserne og udvikling af en politisk blindgyde for arbejderklassen er grobund for udvikling af sociale bevægelser, som må være model og erfaringsgrundlag for, hvordan socialistisk politik kan gro udenfor parlamentet.

\section{Kurasje har tidligere bragt følgende artikler af Mogens Holm:}

»Fagbevægelsens krisestrategi og den statslige indkomstpolitik«, i nr. 18, 1978.

»Hvem plyndrer staten?«, i nr. 26, 1980.

»Tilpasning eller oprør?«, i nr. 27/28 1981. 